\title{
MEMBACA WARNA PADA KARAKTER SUPERHERO MARVEL
}

\author{
Daniar Wikan Setyanto ${ }^{1}$, Bernardus Andang Prasetya Adiwibawa ${ }^{2}$ \\ ${ }^{1,2}$ Desain Komunikasi Visual \\ Fakultas IImu Komputer Universitas Dian Nuswantoro Semarang \\ Jl. Imam Bonjol No.207, Pendrikan Kidul, Semarang, Jawa Tengah 50131 \\ daniarwikan@dsn.dinus.ac.id ${ }^{1}$, andangprast@dsn.dinus.ac.id ${ }^{2}$
}

\begin{abstract}
Abstrak: Saat ini tema superhero sedang menjadi trend film-film Hollywood, secara khusus superhero dari buku komik Marvel. Masyarakat dari segala usia antusias menantikan kehadiran karakter superhero itu dalam film, terbukti bahwa setiap film bertema superhero selalu menjadi box office. Beberapa elemen penting yang menarik dari karakter superhero adalah perawakan fisik, wajah, kekuatan, kostum, dan warna. Warna merupakan salah satu elemen penting dalam karakter superhero karena superhero diidentifikasi dari warna yang melekat pada kostum dan tubuh mereka. Dalam konteks perancangan karakter superhero selain berfungsi estetis, penggunaan warna juga berfungsi untuk mengkomunikasikan sesuatu karena mengandung makna dan filosofi tersembunyi yang memperkuat karakter yang memakainya. Kaitan antara warna dan arti yang tersirat yang ingin dikomunikasikan menjadi titik tolak penelitian ini. Penelitian ini akan mengungkap bagaimana pendefinisian warna, proses semiosis serta efek psikologis warna pada aplikasi kostum superhero. Metode pendekatan yang digunakan adalah deskriptif kualitatif dengan analisis semiotika Roland Barthes. Unit penelitian dalam hal ini adalah karakter superhero komik Marvel.
\end{abstract}

Kata Kunci: Warna, Semiotika, Marvel Comics, Superhero

\begin{abstract}
Nowadays, the superhero genre has become a trend in Hollywood movies, particularly the prominent superhero characters from Marvel Comic. People with different ages anthusiastically wait for the superhero appearance in the movies. It makes every superhero movies become box office. Some of essential elements of the superhero characters are physical appearance, facial expression, their costume and color. The color is one of the essential element since it is embedded in the superheroes' costumes and physical appearance. In term of the fashion and superhero character designs, in addition to aesthetic functions, colors also serve to communicate something because they contain hidden meanings and philosophy that strengthen the characters who wear them. The bound between colors and the implicit meaning things to be communicated is the starting poin or this research. The aim of this research is to discover how to decode color, semiotic process and color-psycological impact on the superheroes' costumes. Method used in this
\end{abstract}

\footnotetext{
${ }^{1}$ Staf pengajar Program Studi DKV dan kepala studio fotografi Fasilkom UDINUS

${ }^{2}$ Staf pengajar Program Studi DKV UDINUS dan peneliti kebudayaan
} 
research is qualitative descriptive approach with Barthes' semiothic analysis. Unit of study for this research is superhero characters from Marvel Comic.

keywords : Color, Semiotic, Marvel Comics, Superhero

\section{PENDAHULUAN}

Superhero, saat ini menjadi tema yang trend dalam film-film Hollywood. Dari sekian banyak superhero yang diangkat ke layar lebar, karakter yang berasal dari buku komik Marvel lebih banyak dikenal oleh masyarakat karena banyak muncul di layar lebar, mulai dari The Avangers, X-Men, Spiderman, Ironman, dan masih ada beberapa yang lain. Kehadiran karakter superhero ini tidak saja dinantikan oleh anak kecil dan remaja namun juga oleh orang-orang dewasa, baik perempuan maupun laki-laki. Hal ini dibuktikan dengan status box office dari setiap film bertema superhero. Data dari situs imdb.com disebutkan bahwa mulai dari film Marvel Universe pertama tahun 2008 sampai 2017 saja marvel telah mengantongi 117 Triliun rupiah dari seluruh dunia, pendapatan tersebut belum termasuk pendapatan lainnya selain dari film seperti asesoris, mainan, games dan lain-lain. Adanya imajinasi masa kecil pada setiap orang dewasa yang merindukan sosok superhero hadir dalam kehidupan nyata diindikasi menjadi sebuah magnet yang membuat tema-tema superhero demikian diminati oleh orang banyak.

Dalam karakter superhero, secara visual melekat beberapa atribut yang menunjuk pada ciri-ciri khusus kelebihan dari karakter itu. Ciri-ciri tersebut antara lain adalah tampilan fisik tokoh atau karakter, kelebihan atau kekuatan super yang dimiliki sang tokoh, kostum yang digunakan dan aksesorisnya, dan warna yang melekat pada kostum dan aksesoris tersebut. Prabowo (2017) menunjukkan bahwa dalam tampilan visual ini terletak nilai estetis sebuah desain, khususnya desain komunikasi visual dan grafis. Prioritas seseorang dalam mengkonsumsi dan menilai baik buruk suatu desain ditentukan melalui tampilan visualnya. 
Dalam konteks fashion selain berfungsi estetis, warna sebagai elemen visual lebih memosisikan diri sebagai the hidden language atau bahasa yang disembunyikan. Setiap pemilihan warna pada sebuah karya visual, baik itu sebuah iklan, film, kemasan, ilustrasi, seni lukis, fotografi dan fashion, terdapat konsep dan tujuan tertentu yang tampil secara sengaja maupun tidak disengaja. Penggunaan warna dengan demikian bukan hanya sebagai pelengkap saja namun juga berfungsi untuk mengkomunikasikan sesuatu. Warna sering dipakai untuk mencerminkan sesuatu arti tersirat yang ingin dikomunikasikan (Krisnawati, 2005).

Pada alur inilah, penelitian tentang warna pada kostum superhero dilakukan. Secara garis besar penelitian ini bertujuan untuk membedah konsepkonsep warna, dan bagaimana warna mampu memberikan persepsi tertentu terhadap otak kita. Dengan menggunakan studi warna yang ada pada kostum superhero sebagai kasus penelitian, diharapkan metode serupa juga dapat digunakan untuk penelitian aplikasi warna pada konteks yang lain. Secara garis besar penelitian ini mencoba menggali potensi yang terdapat pada warna dan fashion, apa saja konsep dan makna yang tersembunyi dan mengapa hal tersebut terjadi.

Dengan teori semiotika sebagai alat kajian diharapkan proses warna sebagai "ada" akan dilengkapi warna sebagai "makna/konsep"dan "bagaimana". Dalam semiotika warna akan diteliti proses semiosisnya, yaitu proses yang menjadikan warna menjadi tanda (yang memiliki makna tertentu), bahkan mengandung mitos tertentu pula. 


\section{KAJIAN LITERATUR}

\section{Tentang Marvel}

Adalah Martin Goodman, keturunan imigran Rusia yang lahir di Broklyn, New York tahun 1908 yang bersama beberapa anggota keluarganya mendirikan perusahaan penerbitan bernama Timely, mengikuti nama majalah yang diterbitkannya Timely Magazine (Howe, 2013). Sebelumnya Goodman telah menerbitkan sekitar 24 majalah termasuk Marvel Science Stories, yang meski tidak memberi keuntungan yang baik, nama Marvel selalu ada di ingatan Goodman.

Pada tanggal 31 Agustus 1939, Timely menerbitkan buku komik pertamanya dengan nama Marvel Comic \#1. Buku komik itu setebal 64 halaman dalam 4 warna. Judul-judul dalam buku itu antara lain; Ka-Zar yang agung (Sang Pangeran Hutan), The Human Torch (Si Manusia Api Marvel), Masked Raider, The Angle, The Sub-mariner, Jungle Terror dan Burning Rubber; kecuali dua judul terakhir, semuanya adalah nama karakter superhero pertama yang dipublikasikan Marvel Comics (Howe, 2013).

Pada laman Marvel Entertainment Group, Inc. History, disebutkan bahwa pasca Perang Dunia II, Goodman mengubah kebijakan perusahaan Timely untuk meningkatkan keuntungan dengan merancang sistem distribusi penerbitan sendiri. Pada tahun 1951, brand perusahaan Timely resmi berubah menjadi Atlas Publishing. Setelah melewati dekade 1950-an yang penuh dinamika di dunia komik dan penerbitan, Atlas Publishing mendapat angin segar setelah pada November 1961, mereka menerbitkan karakter 4 sekawan; The Fantastic Four. Perlahan, Atlas Publishing mulai memperkenalkan brand Marvel pada buku-buku komiknya, hingga pada 1963 resmi buku-buku komik Goodman, mulai menggunakan kata Marvel Comic Group pada setiap sampul bukunya. 
Perubahan drastis terjadi pada pertengahan 1980-an. Marvel Comic Group dijual kepada New World Pictures, sebuah perusahan film yang berminat menerbitkan film animasi berbasis karakter Marvel. Pada bulan Juni, 1991, Marvel memulai babak baru dengan melantai di bursa saham untuk pertama kalinya.

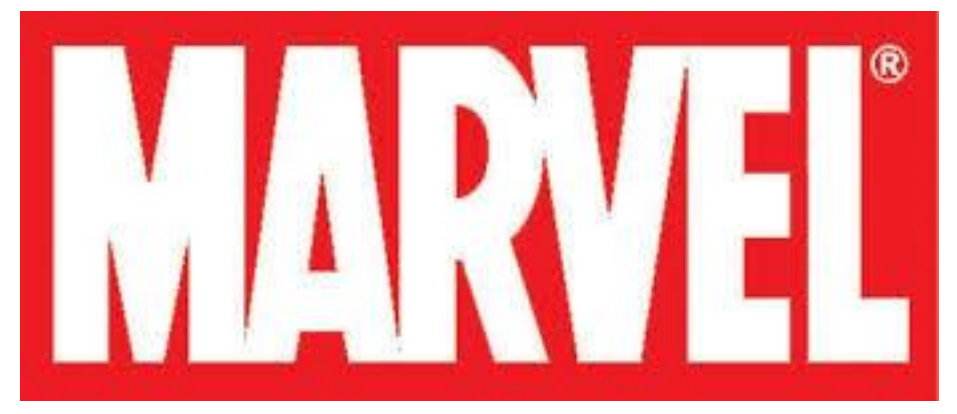

Gambar 1 Logo Marvel sumber : www.marvel.com

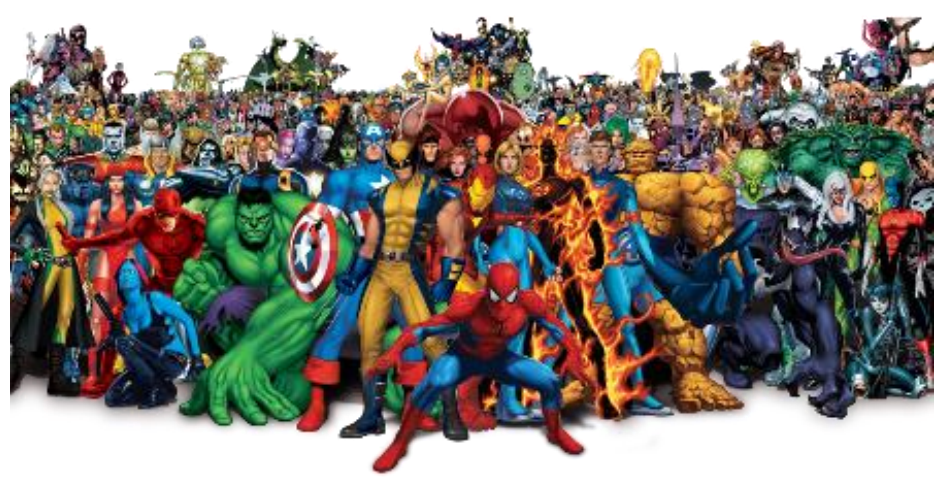

Gambar 2 Tokoh-tokoh Superhero Marvel

Sumber : www.marvel.com

Dari sejarah singkat ini, Marvel telah menerbitkan komik dengan berbagai karakter yang sangat populer seperti Spider-Man, X-Men, Hulk, The Fantastic Four, Iron Man, dan masih banyak lagi. Sebagian besar karakter ciptaan Marvel beroperasi dalam dunia yang dikenal sebagai Dunia Marvel. Perkembangannya kemudian, banyak dari karakter Marvel tersebut yang muncul dalam media hiburan lain seperti serial kartun, film televisi, layar lebar, dan permainan video. 
Marvel juga memiliki situs wikinya sendiri. Situs tersebut diluncurkan pada tahun 2006 dan memuat berbagai informasi dalam jagad Marvel. Pada tahun 2009, The Walt Disney Company menyatakan sepakat untuk membeli Marvel Entertainment sebesar USD 4 miliar dalam transaksi saham dan uang tunai. Dengan demikian, Walt Disney berhak atas karakter komik superhero atau karakter pahlawan berkekuatan super seperti Spider-Man, Iron Man dan X-Men. Kesepakatan tersebut akan memberi Disney kepemilikan lebih dari 5.000 karakter tokoh Marvel Entertainment.

\section{Analisis Semiotika}

Sobur (2004) menyebutkan bahwa tanda bertebaran di mana-mana; tanda ada di sekujur tubuh kita, di depan dan di dalam rumah kita, di mall dan pusat perbelanjaan tradisional. Untuk itu, tanda dipelajari atau dikaji. Semiotika adalah ilmu atau metode analisis yang mengkaji tanda dan makna. Tanda menunjuk pada sesuatu selain dirinya sendiri yang mewakili barang atau sesuatu yang lain, sementara makna merupakan penghubung atara suatu objek dengan suatu tanda (Sobur, 2013).

Analisis semiotika, dewasa ini semakin banyak digunakan dalam kajian ilmiah. Kajian-kajian itu sangat bervariasi, mulai dari satu bagian ritus dalam agama (Hermawan dkk. 2018; Firmansyah dkk, 2016), iklan komersial (Noor dan Ratu Nadya, 2017; Fitriawan dkk. 2016), hingga film atau sinetron (Ratnasari dkk. 2015). Namun dari sekian banyak kajian, pendekatan semiotika yang digunakan pun tidak tunggal; mulai dari pendekatan klasik Charles Sanders Pierce, Saussure, John Fiske hingga yang mutahir Roland Barthes. Setidaknya ada dua konsep penting dalam semiotika Barthes; yang pertama adalah mengikuti jalur Saussure adalah konsep tentang tanda yang arbitrer dan kedua adalah mitos.

Konsep yang pertama, mengikuti pandangan Saussure, ada empat hal penting dalam semiotika (Setyadi, dkk. 2018), salah satunya adalah bahwa tanda 
merupakan bagian yang tidak terpisahkan dengan sistem konvensi (convention) atau sering disebut sistem kesepakatan umum atau sosial. Tanda merupakan gabungan dari sesuatu yang dinamakan signifiant atau signifier atau penanda, dan signifie atau signified atau petanda. Hubungan antara penanda dan petanda sangat ditentukan dengan sistem konvensi yang dalam hal pemaknaan mempunyai otonomi secara penuh.

Menurut Saussure kesepakatan sosial tersebut mengatur sepenuhnya sistem pertandaan sehingga tidak ada kronologis yang muncul secara alamiah dalam sebuah sistem tanda. Sebagai contoh hubungan yang arbitrer dalam sistem tanda bisa kita temui pada kronologis penamaan suatu benda, misalnya "meja" dinamakan meja semata-mata dari dulu dinamakan sebagai "meja", penamaan tersebut tidak berhubungan secara alamiah. Hal tersebut semata-mata terbentuk karena hasil konvensi sosial (Piliang, 2003).

Konsep kedua adalah mitos. Roland Barthes, pemikir stukturalis penerus Saussure, mengemukakan teori penting sehubungan dengan peran pembaca (the reader). Bagi Barthes, agar tanda memiliki fungsi, dibutuhkan keaktifan pembaca. Barthes secara panjang lebar mengulas apa yang disebut dengan sistem pemaknaan tataran ke dua, yang dibangun diatas sistem lain yang telah ada sebelumnya. Sistem kedua ini oleh Barthes disebut dengan konotasi, yang secara tegas dibedakan dari denotasi atau sistem pemaknaan tataran pertama. Hal ini yang memperdalam semiologi Saussure, yang berhenti pada penandaan dalam tataran pertama, denotasi.

Konotasi identik dengan operasi ideologi, atau lebih sering disebut dengan "mitos", dan berfungsi untuk mengungkapkan dan memberikan pembenaran bagi nilai-nilai dominan yang berlaku pada suatu periode yang berlaku. Dalam mitos juga terdapat pola tiga dimensi penanda, petanda, dan tanda. Namun sebagai sesuatu sistem yang unik, mitos dibangun oleh suatu rantai pemaknaan yang telah 
ada sebelumnya. Dalam mitos pula sebuah petanda bisa memiliki beberapa penanda. Artinya dari segi jumlah, petanda lebih miskin jumlahnya dari pada penanda, sehingga dalam taktiknya terjadilah pemunculan konsep secara berulang-ulang dalam bentuk yang berbeda. Mitologi mempelajari bentuk-bentuk tersebut karna pengulangan konsep terjadi dalam wujud yang berbeda-beda.

Barthes menempatkan ideologi bersamaan dengan mitos karena baik dalam mitos maupun ideologi, hubungan penanda konotatif dan petanda konotatif terjadi secara termotivasi. Barthes memahami ideologi sebagai kesadaran palsu yang membuat orang hidup dalam dunia imajinasi yang ideal, meski realitas hidup tidaklah demikian. Ideologi muncul bersamaan dengan kemunculan budaya (Sobur, 2003). Barthes juga berbicara mengenai konotasi sebagai suatu ekspresi budaya. Kebudayaan mewujudkan dirinya dalam suatu sistem mitos bersamaan dengan ideologi yang mewujudkan diri dalam bentuk penanda-penanda penting seperti teks, latar belakang, sudut pandang, dan lainlain.

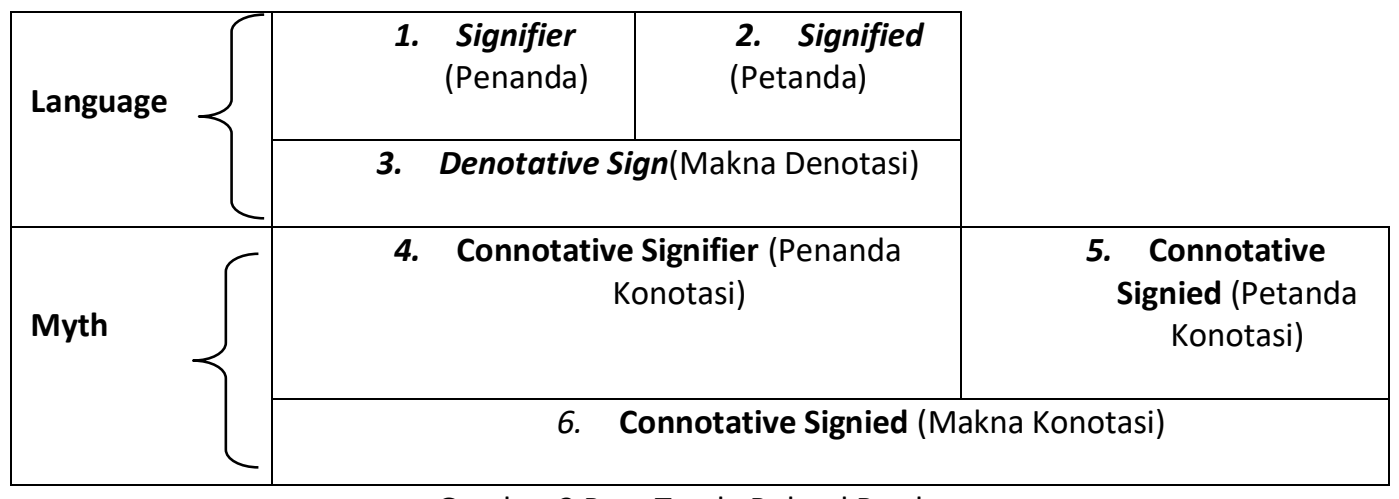

Gambar 3 Peta Tanda Roland Barthes

Sumber : Cobley \& Janez melalui Wibowo, 2015

Jelas terlihat dalam peta Barthes di atas bahwa ada dua tataran pemaknaan; bahasa dan mitos dengan irisan pada penanda konotatif dan petanda konotatif. Dengan demikian, tanda konotatif tidak sekadar memiliki makna 
tambahan namun juga mengandung kedua bagian tanda denotatif yang melandasi keberadaannya (Wibowo, 2015). Dalam hal ini denotasi diasosiasikan pada makna yang tertutup, yang bagi Barthes menjadi hal yang ditolak, karena yang ada hanyalah konotasi. Dalam kerangka inilah mengapa konotasi identik dengan operasi ideologi, yang disebutnya sebagai mitos dan merepresentasikan nilai-nilai dominan secara budaya yang berlaku dalam suatu kurun waktu tertentu. Contohnya seperti kajian Wirasari (2016) tentang tubuh perempuan dalam iklan menunjukkan bahwa tubuh perempuan model iklan itu tidak mendefinisikan dirinya sendiri melainkan situasi, kepentingan produsen serta pihak-pihak lain dalam konteks sebuah iklan ataupun film.

\section{Semiotika dan Warna}

Semiotika mempercayai bahwa setiap tanda yang ada di muka bumi ini selalu mempunyai makna dan pesan. Termasuk juga warna, dalam konteks tertentu warna bukan hanya ekspresi individualistik dan estetika semata, warna muncul karena kebutuhan manusia akan simbol dan keindahan. Lewat warna manusia mencoba mengkomunikasikan sesuatu dengan cara yang non-verbal. Menurut Sobur (2013) komunikasi non-verbal secara harfiah adalah komunikasi tanpa bahasa atau tanpa kata, dan tanda non-verbal adalah tanda minus bahasa atau kata atau teks.

Hakekatnya, studi tentang warna mencakup pencarian pesan dan maknamakna yang tersembunyi dibalik warna. Semiotika sendiri merupakan suatu bidang ilmu yang berbasis pada komunikasi, sebagaimana mempelajari bagaimana proses komunikasi tersebut terjadi dan beroleh "makna", seperti apa perwujudannya, apa tujuannya, bagai mana makna merasuki material warna, dan bagaimana kaitannya dengan pemikiran kita secara umum. Metode semiotika semestinya mampu mengungkapkan makna yang terkandung dalam material warna dalam berbagai macam bentuk pesan-pesan komunikasi. 
Meski disadari juga bahwa dibalik semua fungsi warna yang tampak komunikatif tersebut, sesungguhnya terdapat fungsi-fungsi internal yang tidak dapat diabaikan. Pemikiran internal yang subyektif tersebut turut dalam menentukan pemikiran, persepsi, opini, representasi dan perilaku desainer atau pencipta. Hal tersebut tentunya disebabkan takkala warna dipandang juga sebagai penyampai "imaji". Imaji ini tidak tebatas hanya sesuatu yang kasat mata atau kelihatan saja, melainkan sesuatu yang imajiner, fantasi, tidak terlihat, spiritual dan batiniah. Berikut ini adalah arti warna menurut pakar psikologi warna untuk kesehatan Krisnawati (2005), serta arti warna menurut asosiatifnya.

Tabel 1 Arti Warna Dalam Psikologi

\begin{tabular}{|c|c|}
\hline WARNA & ARTI \\
\hline Merah & Kemasyhuran, asmara, sukses, kemenangan, keberanian, kebahagiaan. \\
\hline Hijau & Kesuburan, keremajaan, penghargaan, kesegaran. \\
\hline Ungu & Kesedihan, kesendirian, kebangsawanan. \\
\hline Biru & Kesetiaan, renungan, ketenangan, kebenaran, idealisme tinggi. \\
\hline Merah & Cinta yang lembut, kasih anak (perempuan), kasih sayang \\
\hline Kuning & Kasih anak (laki-laki) \\
\hline Emas & Keagungan \\
\hline Hitam & Kesucian, kejujuran, damai, kematian, ketidakbahagiaan. \\
\hline Putih & Suci, jujur, kebahagiaan. \\
\hline Kuning & Kerajaan, kebencian, iri hati. \\
\hline
\end{tabular}

Sumber : Krisnawati, 2005

Tabel 2 Arti Warna yang muncul karena asosiasinya

\begin{tabular}{|c|c|c|}
\hline WARNA & Asosiasi & Makna \\
\hline Merah & $\begin{array}{c}\text { Mawar, Darah, } \\
\text { Api }\end{array}$ & $\begin{array}{c}\text { Pengorbanan, sensualitas, cinta, semangat, energi, } \\
\text { perjuangan }\end{array}$ \\
\hline Hijau & Tumbuhan, & Alami, kesuburan \\
\hline Biru & Langit, air & Ketenangan, kemurnian, kesegaran \\
\hline Kuning & Matahari, emas & Cahaya, kekuatan, terang, kemuliaan \\
\hline Hitam & Malam, & Misteri, kekuatan, kesunyian \\
\hline
\end{tabular}

Sumber : Setyanto dan Adiwibawa, 2018

Secara obyektif, menurut Krisnawati (2005), terciptanya warna karena adanya pigmen. Dalam industri percetakan yang terkait erat dengan desain 
komunikasi visual atau desain grafis, agar dapat menghasilkan warna yang bervariasi ditetapkan penggunaan warna substraktif; cyan (C), magenta (M), yellow (Y) dan hitam (Black/ K), atau dikenal istilah CMYK. Sementara di sisi lain secara alamiah dikenal spektrum cahaya yang terentang dari warna merah (gelombang cahaya tertinggi 630-760 nm) hingga ungu (gelombang cahaya terendah 380-450 $\mathrm{nm}$ ).

Apabila mengacu pada tabel 2 tentunya makna warna pada karakter superhero tentu menjadi tidak relevan karena selain berfungsi sebagai elemen artistik warna pada karakter superhero juga berfungsi dalam membentuk citra positif dari karakter tersebut. Dengan demikian konteks warna pada kesehatan dan makna yang muncul karena sifat asosiatifnya tidak bisa langsung diterapkan dengan konteks warna pada konteks karakter superhero. Makna warna pada karakter superhero tentunya juga melibatkan proses semiotik yang melibatkan elemen-elemen lain diluar warna itu sendiri.

\section{METODE PENELITIAN}

Berdasarkan latar belakang masalah maka penelitian ini juga menggunakan metode deskriptif kualitatif yaitu suatu prosedur penelitian yang menggunakan data deskriptif berupa kata-kata tertulis atau lisan dari orang-orang dan pelaku yang dapat diamati (Sugiyono, 2012). Dalam konteks media massa, kajian semiotika ini juga mengusut ideologi-ideologi yang melatari materi estetika yang dalam hal ini adalah warna yang dipakai di kostum superhero Marvel.

Keunggulan metode deskriptif kualitatif adalah dapat mengungkap fakta, keadaan, dan fenomena yang terjadi pada saat penelitian berjalan dan menyuguhkan data dengan lebih nyata. Metode tersebut memaparkan situasi dan fenomena populernya karakter superhero Marvel pada saat ini dan bagaimana warna pada karakter tersebut dapat memberikan dampak psikologi maupun 
pemaknaan pada penontonnya. Dengan pendekatan tersebut diharapkan dapat menghasilkan perancangan yang sistematis, aktual, dan menarik mengenai objek penelitian dan perancangan. Berdasarkan Suyanto \& Sutinah (2006), pertimbangan penggunaan rancangan ini adalah: (1) data yang akan diambil bersifat alamiah atau wajar dengan konteks utuh (holistik), (2) Instrumen penelitian baik peneliti dan sumber data berupa manusia (human instrument), (3) metode pengumpulan data observasi sebagai metode utama, (4) analisis data dilakukan secara induktif dengan pendekatan teori semiotika secara khusus semiologi Barthesian.

Untuk membatasi obyek yang dikaji, penelitian mengambil sampel 18 karakter populer kemudian dikerucutkan kembali menjadi 2 karakter yang muncul dalam 3 semesta cinematik yatu Marvel Cinematic Universe (MCU), X-men Cinematic Universe (XMU) dan Defender Universe (DU) periode 2008-2013. Pembatasan diperlukan karena dalam beberapa visualisasi karakter Marvel digambarkan memiliki kostum yang berbeda dengan yang ada di komik aslinya. Dua karakter yang dikaji adalah Ironman dan Black Widow yang mewakili dua warna dominan yang dipakai oleh karakter dalam superhero marvel yaitu warna merah dan hitam. Dalam mendefiniskan warna, penelitian ini juga mengabaikan aspek gelap terang warna (value) sehingga merah tua tetap disebut merah, biru tua tetap disebut biru dan seterusnya.

\section{HASIL DAN DISKUSI}

Ada banyak karakter superhero yang diciptakan oleh Marvel. Di bawah ini adalah tabel yang berisi karakter superhero yang menjadi tokoh utama dalam kisah dalam cerita komik serta warna yang dipakai oleh karakter tersebut : 
Tabel 3 Karakter Superhero Marvel dan warna yang digunakan

\begin{tabular}{|c|c|c|c|c|}
\hline Superhero & $\begin{array}{l}\text { Warna } \\
\text { Dominan }\end{array}$ & $\begin{array}{l}\text { Warna } \\
\text { aksen } 1\end{array}$ & $\begin{array}{l}\text { Warna } \\
\text { aksen } 2\end{array}$ & Aktor/Artis \\
\hline Spiderman & MERAH (60\%) & $\begin{array}{l}\text { BIRU } \\
(40 \%)\end{array}$ & - & Tom Holland \\
\hline Ironman & $\begin{array}{l}\text { MERAH } \\
(90 \%)\end{array}$ & $\begin{array}{l}\text { KUNING } \\
\text { EMAS } \\
(10 \%)\end{array}$ & - & $\begin{array}{l}\text { Robert } \\
\text { Downey Jr. }\end{array}$ \\
\hline Dea & $\begin{array}{l}\text { MERAH } \\
(80 \%)\end{array}$ & $\begin{array}{l}\text { HITAM } \\
(20 \%)\end{array}$ & - & Ryan Renold \\
\hline Dar & $\begin{array}{l}\text { MERAH } \\
(100 \%)\end{array}$ & - & - & Charlie Cox \\
\hline Antman & $\begin{array}{l}\text { MERAH } \\
(50 \%)\end{array}$ & $\begin{array}{l}\text { HITAM } \\
(40 \%)\end{array}$ & $\begin{array}{l}\text { PUTIH } \\
(10 \%)\end{array}$ & Paul Rudd \\
\hline Thor & $\begin{array}{l}A B U-A B U \\
(70 \%)\end{array}$ & $\begin{array}{l}\text { MERAH } \\
(30 \%)\end{array}$ & - & $\begin{array}{l}\text { Chris } \\
\text { Hemsworth }\end{array}$ \\
\hline
\end{tabular}




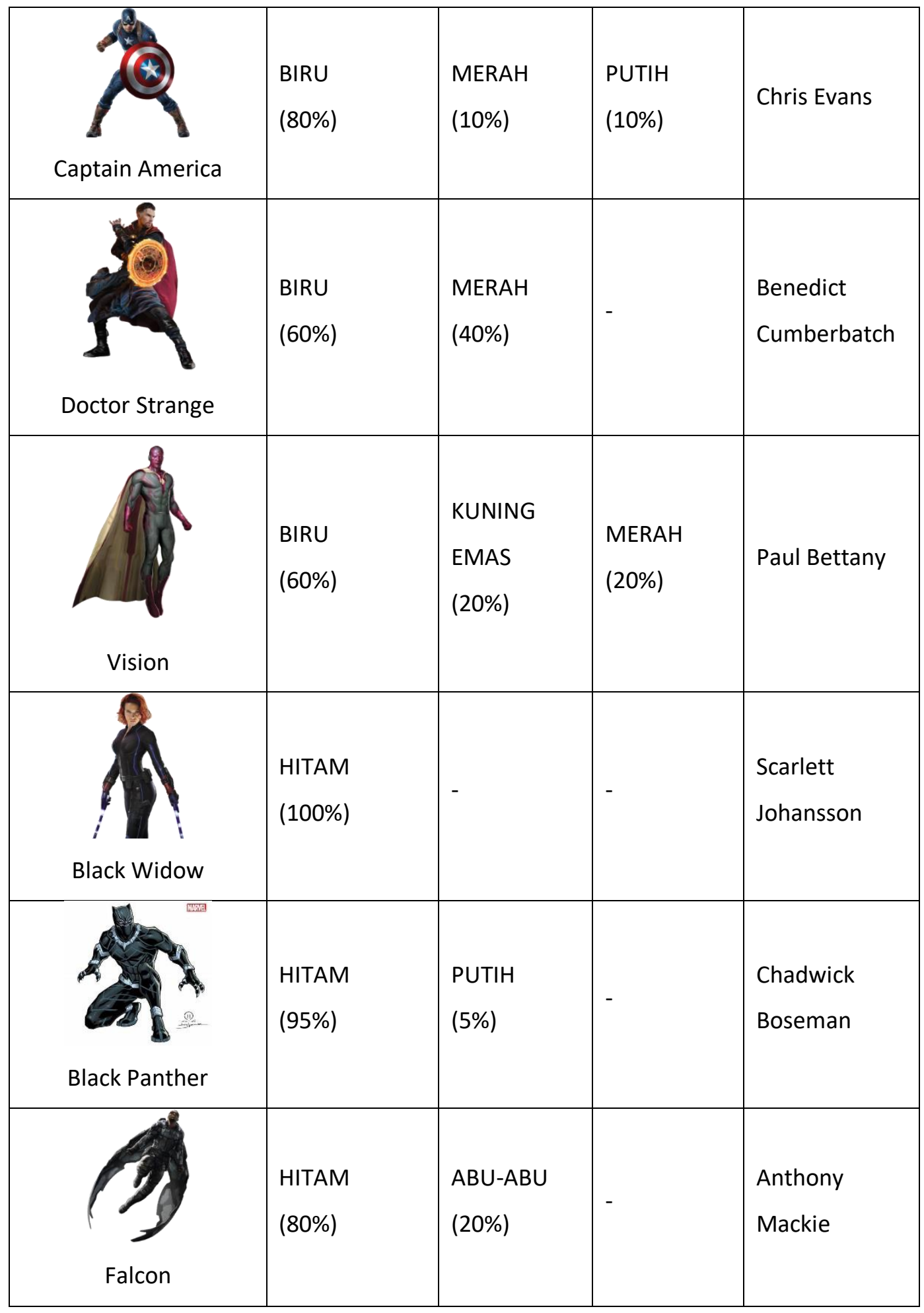




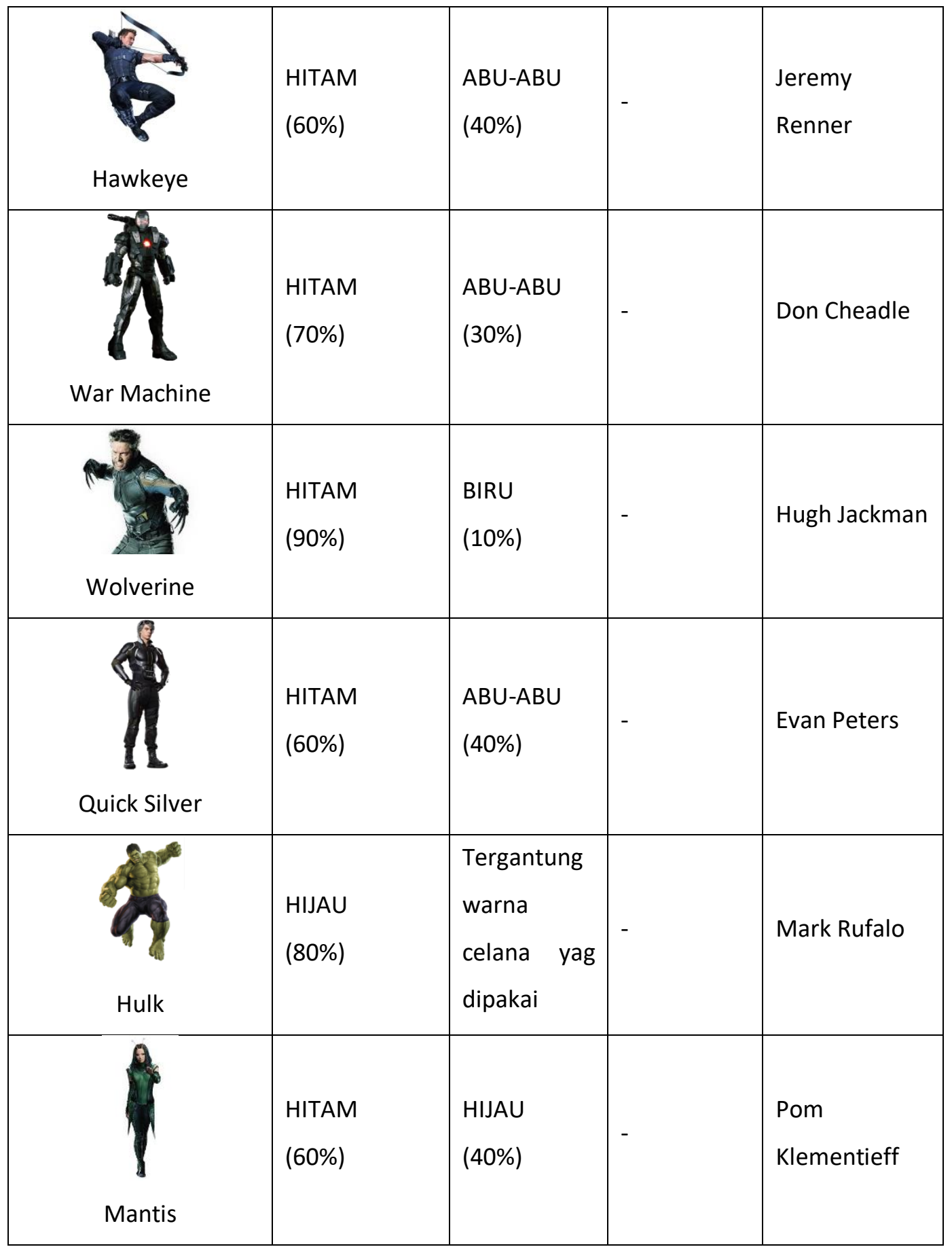

Sumber : Setyanto dan Adiwibawa, 2018 
Dari tabel di atas dapat disimpulkan bahwa warna dominan hitam dipakai 8 karakter, warna dominasi merah dipakai 5 karakter, warna dominan biru dipakai di 3 karakter, sedangkan hijau dan abu-abu masing masing dipakai 1 karakter. Sedangkan untuk warna aksen yang paling banyak dipakai adalah warna aksen merah dan abu-abu masing-masing dipakai 4 karakter, kemudian warna aksen putih sebanyak 3 karakter, dan warna aksen hitam, biru dan kuning masing-masing 2 karakter. Untuk membatasi ranah warna pada penelitian ini akan difokuskan pada 2 warna yang paling banyak muncul pada karakter superhero Marvel yaitu warna Hitam dan Merah, nantinya proses pemaknaan pada warna Hitam dan Merah juga bisa diterapkan pada warna-warna lainnya.

Dalam sebuah sistem pertandaan sering dijumpai sebuah gambar/obyek manusia dengan berbagai macam dinamikanya. Manusia sarat dengan makna, manusia dapat memberdayakan makna dalam berbagai macam manifestasi. Manusia yang dimaksud di sini merupakan sebuah entitas kongkrit yang murni, manusia yang telanjang, manusia dengan berbagai macam bahasa tubuh dan ekspresi. Manusia bahkan dalam ketelanjangannya membawa banyak tanda. Atribut merupakan obyek pelengkap dalam sistem pertandaan. Fungsi atribut bukan hanya berupa pelengkap saja namun juga sebagai penghias dan penguat makna. Tanda akan bermakna apabila tanda tersebut memiliki sebuah atribut. Sebuah obyek dapat dikatakan sebagai atribut ketika obyek tersebut tidak mendominasi sebuah sistem pertandaan, sebaliknya apabila obyek tersebut bersifat dominan maka obyek tersebut dapat dikatakan sebagai penanda utama.

Pemikiran tersebut dapat kita sejajarkan dengan pendapat Saussure mengenai berfungsinya tanda secara individual. Menurut Saussure, tanda (yang merupakan hubungan internal antara penanda dan petanda) berfungsi dalam sebuah dimensi yang berfungsi "mendenotasikan"; pendapat ini diperkuat juga oleh Lois Hjelmslev yang mengatakan bahwa tanda mengandung dimensi yang 
didalamnya terbagi menjadi dimensi-dimensi lain yang lebih kecil. Sebuah dimensi yang seandainya disertakan, akan mengakibatkan transformasi. Tanda bukan sesuatu yang dapat berdiri sendiri, namun hadir dalam beban-beban informasi yang datang dari luar tanda itu sendiri (Cobley, 1997). Sebuah tanda tidak hanya mengandung hubungan internal antara aspek material (penanda) dan konsep (petanda), tetapi juga berhubungan dengan sistem yang lebih luas di luar maupun di dalam dirinya sendiri. Yang dimaksud sistem di dalam tanda inilah yang kemudian dikemas dengan istilah yang disebut atribut. Penelitian ini menggunakan pemikiran pokok yang mendasar pada pendekatan figur sebagai atribut karena makna warna pada karakter superhero ikut diperkuat dengan figur pada karakter tersebut.

Manusia tidak pernah lepas dari identitasnya, dimana identitas tersebut selalu membawa makna kapasitas tertentu. Identitas seseorang merupakan hasil dari sebuah perjalanan karier dan prestasi tertentu yang kemudian membentuk keidentikan pada kapasitas tertentu. Pemilihan figur yang tepat dalam sebuah sistem pertandaan dapat membantu memunculkan makna warna yang monoistik tanpa ada salah persepsi. Sebagaimana contoh pemilihan artis Scarlet Johansson sebagai pemeran Black Widow tentu akan memiliki fungsi penting dalam proses pemaknaan warna hitam pada karakter tersebut. Scarlet Johansson merupakan artis yang pada tahun 2006 pernah dinobatkan sebagai salah satu dari 100 perempuan paling sexy di dunia versi majalah Forbes. Dengan demikian citra sebagai perempuan cantik dan sexy tentunya akan mempengaruhi dari makna hitam yang identik dengan perannya sebagai Black Widow. Demikian juga warna merah dari Ironman akan dipengaruhi oleh citra yang ada pada Robert Downey, jr yang merepresentasikan makna kemewahan. Hal tersebut dikarenakan Robert Downey, jr merupakan aktor yang pernah dinobatkan sebagai aktor berpenghasilan tertinggi di dunia versi majalah Forbes pada tahun 2015 dengan bayaran tertinggi mencapai $\$ 80$ juta. 


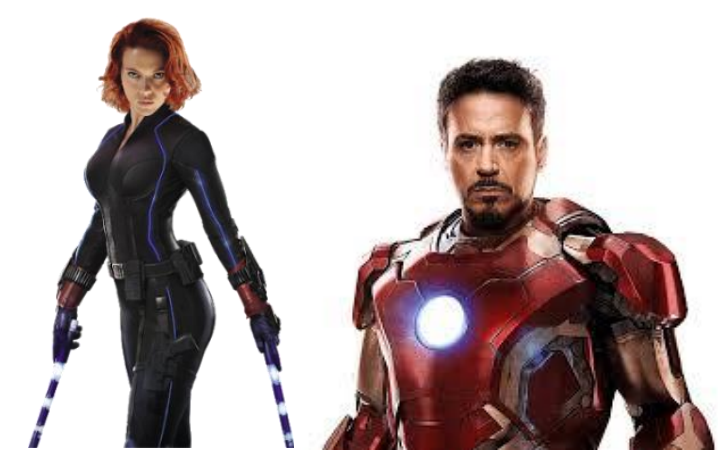

Gambar 3 karakter Natasha Romanov/Black Widow yang diperankan oleh Scarlet Johansson dan Tony Stark/Ironman yang diperankan oleh Robert Downey Jr.

Sumber : www.marvel.com

Apabila kita melihat dalam konsep teori mitos Barthes, tanda konotatif pada warna tidak sekadar memiliki makna tambahan namun juga mengandung kedua bagian tanda denotatif yang melandasi keberadaannya. Di dalam Semiologi Barthes dan para pengikutnya, denotasi merupakan sistem signifikasi tingkat pertama, sedangkan mitos merupakan signifikasi tingkat kedua yang berhubungan dengan atribut dimana warna tersebut melekat.

Tabel 2 Proses pemaknaan warna Hitam pada karakter superhero Black Widow menggunakan peta tanda Roland Barthes

\begin{tabular}{|c|c|c|}
\hline \begin{tabular}{l}
\multicolumn{2}{c|}{ Penanda } \\
Merupakan \\
citra dari \\
warna hitam \\
itu sendiri.
\end{tabular} & $\begin{array}{l}\text { Petanda } \\
\text { Merupakan tanda tingkat } \\
\text { pertama atau makna } \\
\text { denotasi. Dalam hal ini } \\
\text { Hitam adalah representasi } \\
\text { dari palet warna C:0 M:0 Y:0 } \\
\text { K:0 atau R:0 G:0 B:0 }\end{array}$ & \\
\hline \multicolumn{2}{|c|}{$\begin{array}{l}\text { Makna Denotasi } \\
\text { Hitam adalah definisi dari ketidakhadiran } \\
\text { cahaya dalam sebuah benda }\end{array}$} & \\
\hline \multicolumn{2}{|c|}{$\begin{array}{l}\text { Penanda Konotasi } \\
\text { an penanda berupa obyek atribut } \\
\text { ekat secara langsung seperti corak } \\
\text { an figur yang digunakan dan asosiasi } \\
\text { ng identik warna hitam contoh : } \\
\text { ri }\end{array}$} & $\begin{array}{l}\text { Petanda Konotasi } \\
\text { Merupakan representasi yang muncul dari } \\
\text { sosok figur Scarlet Johansson pada karakter } \\
\text { Natasha Romanov/Black Widow dan sifat } \\
\text { identik dari obyek yang identik dengan malam } \\
\text { hari. }\end{array}$ \\
\hline \multicolumn{3}{|c|}{ Makna Konotasi } \\
\hline
\end{tabular}

Sumber : Setyanto dan Adiwibawa, 2018 
Tabel 3 Proses pemaknaan warna Merah pada karakter superhero Iron Man menggunakan peta tanda Roland Barthes

\begin{tabular}{|c|c|c|}
\hline $\begin{array}{l}\text { Penanda } \\
\text { Merupakan } \\
\text { citra dari } \\
\text { warna merah } \\
\text { itu sendiri. }\end{array}$ & $\begin{array}{l}\text { Petanda } \\
\text { Merupakan tanda tingkat } \\
\text { pertama atau makna } \\
\text { denotasi. Dalam hal ini } \\
\text { Merah adalah representasi } \\
\text { dari palet warna C:0 M:100 } \\
\text { Y:100 K:0 atau R:100 G:0 B:0 }\end{array}$ & \\
\hline \multicolumn{2}{|c|}{$\begin{array}{l}\text { Warna merah adalah warna yang muncul } \\
\text { pada frekuensi yang paling rendah yang } \\
\text { memiliki panjang gelombang diantara 630- } \\
760 \text { nanometer. (Kristina, 2005) }\end{array}$} & \\
\hline \multicolumn{2}{|c|}{$\begin{array}{l}\text { Penanda Konotasi } \\
\text { Merupakan penanda berupa obyek atribut } \\
\text { yang melekat secara langsung seperti corak } \\
\text { kostum dan figur yang digunakan dan asosiasi } \\
\text { obyek yang identik warna merah contoh : } \\
\text { bunga mawar, api, darah }\end{array}$} & $\begin{array}{l}\text { Petanda Konotasi } \\
\text { Merupakan representasi yang muncul dari } \\
\text { sosok figur Robert Downey Jr pada karakter } \\
\text { Tony Stark/Iron Man dan sifat identik dari } \\
\text { obyek yang identik dengan bunga mawar, api, } \\
\text { darah. }\end{array}$ \\
\hline \multicolumn{3}{|c|}{$\begin{array}{l}\text { Makna Konotasi } \\
\text { ahan, Kekuatan, pa }\end{array}$} \\
\hline
\end{tabular}

Sumber : Setyanto dan Adiwibawa, 2018

\section{KESIMPULAN DAN SARAN}

Hasil pemaknaan warna melalui peta tanda Roland Barthes di atas menunjukkan bahwa warna tidak dapat dimaknai tanpa dikaitkan dengan aspek lain di luar dirinya. Dalam studi kasus atribut warna pada kostum karakter superhero, makna warna pada tingkat pertama hanya memunculkan makna denotasi yaitu sebagaimana munculnya warna pada palet CMYK atau RGB dan panjang gelombangnya. Baru pada pemaknaan tingkat kedua, makna konotasi pada warna muncul akibat adanya aspek lain dalam wujud asosiasi dan figur pemeran karakter tersebut. Maka setidaknya ada tiga hal yang dapat digarisbawahi dari penelitian ini.

Pertama, warna telah diasosiasikan pada suatu benda tertentu. Asosiasi disini adalah warna diidentikkan pada benda tertentu. Misalnya warna hitam 
diasosiasikan dengan "malam hari". Oleh karena itu warna hitam bisa diartikan dengan sifat-sifat yang dibawa oleh "malam hari" seperti misteri, ketakutan, kekuatan, kegelapan dll. Warna hitam tidak bisa mewakili definisi segar karena segar diasosiasikan pada laut yang warnanya biru muda, atau pada jeruk yang warnanya oranye.

Kedua, sifat arbriter yang terlalu kuat. Sifat arbriter yang terlalu kuat dan sejak lama melekat dalam masyarakat dapat membuat definisi warna menjadi seakan-akan ilmiah. Karena dulu warna merah berarti atau diartikan berani dan putih berarti suci, maka demikian jadinya. Karena masyarakat tidak bisa menemukan kajian untuk mendukung maupun menolak definisi tersebut.

Ketiga, warna hanya penguat citra atribut. Mendefinisikan warna tidak bisa dilakukan dengan cara melihat warna yang berdiri sendiri. contohnya kotak polos berwarna hitam tidak akan bisa diartikan apapun, sedang warna hitam yang dipakai oleh orang yang sedang menangis di sebelah makam sangat bisa menguatkan arti dari dukacita. Warna hitam pada HP dan mobil bisa menguatkan kesan elegan dan mewah. Hal tersebut dikarenakan warna "hanya" sebagai penguat saja. Sedang element yang dominan adalah atribut yang menyertainya, dalam kasus warna pada karakter superhero ayang berperan penting pada proses pemaknaan adalah aktor dan artis yang membawakan karakter tersebut, dan bagaimana karakter superhero tersebut ditampilkan.

Hasil yang didapatkan dari penelitian ini diharapkan juga dapat digunakan untuk mengkaji atau membaca peranan semua warna pada proses penciptaan karakter baik superhero maupun yang bukan karakter superhero, karena teori dari semiotika Roland Barthes juga bisa digunakan untuk membaca setiap tanda yang ada pada desain karakter. Yang terpenting dari Semiotika Barthes dalam membaca peran warna justru ada pada tanda lain yang menempel pada warna tersebut 
seperti bagaimana karakter tersebut ditampilkan, atribut yang digunakan, aktor yang memerankan serta unsur-unsur asosiatif yang melekat pada warna. Dengan demikian peran teori Semiotika dalam membaca warna pada desain karakter tentunya akan menjadi lebih lengkap ketika semiotika juga berperan dalam proses penciptaannya, oleh karena itu untuk penelitian lanjutan tema penciptaan desain karakter dengan penggunaan dominasi warna sebagai representasinya akan diperlukan untuk melengkapi penelitian ini.

\section{DAFTAR PUSTAKA}

Piliang, Y.A., 2003. Hipersemiotika, Jalasutra, Yogyakarta

Cobley, Paul \& Janez, Litza, 1999. Introduction Semiotic. New York. Totem Press Firmansyah, M.R., dkk 2016. Pemaknaan Desain Poster Dakwah Parodi pada Instagram Pemuda Hijrah; analisis semiotika Roland Barthes. e-Proceeding of Management : Vol.3. No.3. pp 3832-3839

Fitriawan, R.A., dkk, 2016. Makna Hidup Iklan Rokok di Televisi; analisis semiotika John Fiske terhadap iklan rokok A Mild Go Ahead versi langkah. eProceeding of Management : Vol.3. No.3. pp 3713-3732

Hermawan, I.W.G., dkk, 2018. Semiotika Komunikasi dalam Tradisi Penabeng di Desa Pakraman Batuyang Kecamatan Sukawati, Kabupaten Gianyar. Jurnal Penelitian Agama Hindu. Institut Hindu Dharma Negeri Denpasar. Vol. 2. No. 1. pp 181-186

Howe, G.L., 2013. Anestesi lokal. Jakarta: Hipokrates

Krisnawati, C., 2005. Terapi Warna dalam Kesehatan : Energy Colour Theraphy, Curiosita, Jogjakarta

Marvel Entertainment Group, Inc. History. dalam International Directory of Company Histories, Vol. 10. St. James Press, 1995. diakses pada 22 Juni 2018 pukul 14.05 WIB di http://www.fundinguniverse.com/companyhistories/Marvel-entertainment-group inc-history/

Noor, F. dan Ratu, N.W., 2017. Representasi Sensualitas Perempuan dalam Iklan New Era Boots di Televisi; kajian semiotika Roland Barthes. IkraithHumaniora. Vol. 1. No. 2. 
Ratnasari, D. H.C. dan Hasyim, M., 2015. Perselingkuhan dan Kesetiaan dalam Sinetron "Catatan Hati Seorang Istri"; suatu studi analisis komunikasi keluarga dalam perspektif semiotika. Jurnal Komunikasi KAREBA. Vol. 4. No.3. pp 270-286

Prabowo, A., Khamadi, K., Haryadi, T. dan Yudani, H.D., 2017.Persepsi Visual Karakter Warrior pada Game Online Warcraft, Perfect World, dan Nusantara Online. Desain Komunikasi Visual, Manajemen Desain dan Periklanan (Demandia), Vol 02, No 02, pp.160-181.

Setyadi, M.A, Putri, Y.R. dan Putra, A., 2018. Analisis Semiotika Ferdinand de Saussure sebagai Representasi Nilai Kemanusiaan dalam Film the Call.eProceeding of Management : Vol.5. No.1. pp 1251-1258

Sobur, A., 2003. Semiotika Komunikasi. Bandung: PT. Remaja Rosda Karya Sobur, A., 2004. Analisis Teks Media: Suatu Pengantar untuk Analisis Wacana, Analisis Semiotik, dan Analisis Framing. Bandung.Penerbit RemajaRosdakarya.

Sugiyono., 2012. Metode Penelitian Kuantitatif Kualitatif dan R\&D. Bandung: Alfabeta.

Suyanto dan Sutinah. 2006. Metode Penelitian Sosial Berbagai Alternatif Pendekatan. Jakarta: Prenada Media Group

Tohir, M., 2016, Mengungkap Retorika Iklan Melalui Pendekatan Semiotika Studi Kasus pada Iklan FedEx, Desain Komunikasi Visual, Manajemen Desain dan Periklanan (Demandia), Vol 01, No 01, pp 34-44

Wibowo, E.A., 2015. Analisis Semiotika Representasi Perempuan dalam Film Wanita Tetap Wanita (Doctoral dissertation, Universitas Muhammadiyah Surakarta).

Wirasari, I., 2016. Kajian Kecantikan Kaum Perempuan Dalam Iklan, Desain Komunikasi Visual, Manajemen Desain dan Periklanan (Demandia), Vol 01, NO 02, pp 146-156 